\title{
Borgerinddragelse, videnskab og ekspertise Deliberation om biodiversitet
}

\author{
Birgit Jæger \\ Professor, Institut for Samfund og Globalisering, Roskilde Universitet (RUC)
}

Alle er lige, men nogle er mere lige end andre det gælder måske særligt i forholdet mellem videnskab og borgere. Birgit Jæger sætter fokus på framing og magt i deliberative processer. Hun viser, hvordan materiale udleveret i en borgerinddragelsesproces om biodiversitet er stærkt præget af naturvidenskabelige diskurser. Derefter argumenterer hun for, at de kommer til at sætte dagsordenen for resten af diskussionerne i en sådan grad, at man kan spørge sig selv, om inddragelsen af borgere overhovedet giver mening, hvis de videnskabelige udsagn alligevel bliver altoverskyggende.

Almindelige borgere - eller lægfolk - kan ytre sig om komplekse videnskabelige og teknologiske problemer på mange forskellige måder. I Danmark har vi en forholdsvis lang tradition for at inddrage borgere i sådanne diskussioner gennem strukturerede gruppeprocesser. Traditionen blev institutionaliseret, da Teknologirådet blev oprettet i 1986 med det formål at lave teknologivurderinger (Klüver 1995), men i årenes løb er emnerne blevet bredere, og i dag bliver borgerne også inddraget i bredere videnskabelige problemstillinger som $\mathrm{fx}$ biodiversitet og klimaforandringer (Agger et al. 2012). Når borgerne inddrages i strukturerede gruppeprocesser med henblik på at rådgive politikerne om, hvilke løsninger der skal tages $\mathrm{i}$ anvendelse, er det ikke tilstrækkeligt, at deres rådgivning udelukkende bygger på deres erfaringer som borgere. Det er også nødvendigt at inddrage den videnskabelige viden, der eksisterer på det pågældende område. Spørgsmålet er imidlertid, hvordan den videnskabelige viden bliver præsenteret for borgerne, og hvordan borgerne forholder sig til den i deres indbyrdes dialog, når de skal finde frem til de råd, som de vil sende videre til politikerne?
For at svare på disse spørgsmål vælger jeg at slå ned på en bestemt form for struktureret dialog mellem borgere, kaldet: World Wide Views. Metoden er udviklet af Teknologirådet, og som navnet antyder, er det en metode, der er udviklet til at inddrage borgere i globale borgerhøringer (Bedsted et al. 2012). World Wide Views blev gennemført første gang i 2009 som optakt til FN's klima topmøde i København. Anden gang metoden blev anvendt var som optakt til FN's topmøde om biodiversitet i 2012, og det er dette arrangement, jeg tager empirisk afsæt i i denne artikel.

Men hvorfor er det overhovedet nødvendigt at inddrage borgere i løsningen af den slags problemstillinger? Er det ikke bedre at overlade beslutningerne til politikere og eksperter? Der er mindst to gode grunde til at inddrage borgerne. Den ene grund er, at den videnskabelige viden, som eksperterne fremlægger, ikke er tilstrækkelig til at danne udgangspunkt for politiske løsninger af komplekse videnskabelige og teknologiske problemer. For at danne baggrund for sådanne beslutninger skal den videnskabelige viden suppleres med andre former for viden og erfaringer, så den bliver 'socialt robust'. Den anden grund er funderet i et demokratisk perspektiv - det deliberative demokrati - der tager som udgangspunkt, at politiske beslutninger først er legitime, når de befolkningsgrupper, der bliver berørt af konsekvenserne af beslutningen, er blevet hørt.

I det følgende afsnit bliver disse to perspektiver nærmere foldet ud og udgør hermed en teoretisk ramme for at svare på spørgsmålet om, hvordan videnskabelig viden indgår i borgernes dialog om komplekse problemer. Herefter følger en kort beskrivelse af Teknologirådets arbejde med forskellige metoder til inddragelse af borgere i dialogen om videnskabelige og teknologiske problemstillinger. Dernæst præsenterer jeg en empirisk analyse af, hvordan videnskabelig viden indgik i borgernes dialog på den danske del af World Wide Views - Biodiversitet. ${ }^{1}$ Analysen 
falder i to dele, idet jeg starter med at undersøge, hvordan den videnskabelige viden om biodiversitet blev præsenteret for borgerne gennem det informationshæfte, der blev udsendt til samtlige deltagere op til arrangementet. Dernæst dykker jeg ned i dialogen omkring et af bordene, hvor jeg ser på, hvordan borgerne bruger den videnskabelige viden i deres indbyrdes dialog. Til slut runder jeg af med at konkludere på, hvad min analyse har vist om hvordan videnskabelig viden indgår i borgeres dialog om biodiversitet.

\section{Borgerdialog og Videnskab - en teoretisk ramme}

Når politikere skal træffe vigtige politiske beslutninger for at løse komplekse problemer, er det helt almindeligt, at de beder videnskabelige eksperter om råd. Videnskabelig viden indgår dermed som et vigtigt element i styringen af et demokratisk samfund på linje med input fra interessegrupper, lobbyister m.m. Forskning inden for Science and Technology Studies (STS) har imidlertid vist, at videnskabelig viden ikke er den eneste form for ekspertise, der er relevant at inddrage i beslutningsprocessen. I visse tilfælde er det også nødvendigt at inddrage den viden, der opstår blandt mennesker med praktisk erfaring, som ikke er forskere og ikke umiddelbart anses for at være eksperter.

I et klassisk STS-studie viser Wynne (1989) således, at forskere ikke var de eneste eksperter, det var relevant at inddrage $\mathrm{i}$ håndteringen af radioaktivt nedfald fra atomudslippet i Tjernobyl, da det ramte England. Det viste sig, at fåreavlere, der levede i nærheden af atomkraftværket Sellafield, efter mange års små atomudslip havde opbygget en viden om, hvordan atomudslip påvirker det lokale økosystem, fårenes adfærd og græssets vækst. Denne viden var lige så vigtig at inddrage i løsningen af problemet med atomudslippet fra Tjernobyl. Studier som dette har ført til en længere diskussion om, hvem der er eksperter, hvad der karakteriserer ekspertviden ( $f x$ Collins \& Evans 2002), og hvordan ekspertviden bliver inddraget i politiske beslutningsprocesser.

Et af svarene på disse spørgsmål kommer fra Nowotny (2003), der foreslår en form for pluralistisk ekspertise som grundlag for styringen af et demokratisk samfund. Hun argumenter således for, at det er nødvendigt at gå fra 'reliable knowledge' - som kendetegner den videnskabelige viden - til det hun kalder 'socially robust knowledge' (Nowotny et al. 2001, Nowotny 2003).

Socialt robust viden tager afsæt i videnskabelig viden, men derudover er den kendetegnet ved følgende tre parametre: 1) Socialt robust viden er ikke kun testet og afprøvet i laboratorier og andre videnskabelige sammenhænge, den er også afprøvet uden for laboratoriet i konkrete samfundsmæssige sammenhænge. 2) I og med at socialt robust viden bliver testet i samfundsmæssige sammenhænge, bliver andre grupper end forskere inddraget i testen. Der kan være tale om andre eksperter (a la Wynnes fåreavlere) eller lægfolk i al almindelighed. Hermed bliver andre typer af viden inddraget og koblet til den videnskabelige viden. Eller som Nowotny beskriver det: „Bringing together the many different knowledge dimensions involved constitutes specific mixes with other kinds of knowledge, experience and expertise." (Nowotny 2003, 155). 3) Socialt robust viden er derfor en viden, der er blevet testet i samfundsmæssige sammenhænge, modificeret og udvidet ikke bare én, men gentagne gange. I forlængelse af dette beskriver Nowotny socialt robust viden som en relationel term. Den beskriver de processer, hvorunder viden bliver skabt, og ikke nødvendigvis et færdigt produkt (Nowotny 2003)

Med dette udgangspunkt bliver borgere - eller lægfolk - en vigtig gruppe at inddrage, når formålet er at skabe socialt robust viden, der kan bruges som input til den politiske beslutningsproces. World Wide Views kan dermed forstås som et institutionaliseret led i processen at skabe socialt robust viden. Når borgerne bidrager til denne proces, forventes det, at de kan bidrage med etiske, moralske og sociale parametre, som udspringer af deres egne erfaringer. Men det forventes også, at borgerne er i stand til at kunne forholde sig til videnskabelig viden og relatere denne viden til deres egne erfaringer som samfundsborgere, og dermed praktisere det Irwin (2001) kalder et 'Scientific Citizenship'. For at kunne udøve denne form for videnskabeligt medborgerskab er det nødvendigt, at borgerne er i stand til at kigge eksperterne over skulderen, og at de stiller krav om, at det er den nødvendige og passende videnskabelige viden, der bliver lagt frem (Jasanoff 2003). Ud fra erfaringer med forskellige former for struktureret borgerinddragelse har Rayner (2003) kortlagt følgende forventninger til borgere, der deltager i disse arrangementer. De skal være: „... socially embedded in a community; locally knowledgeable and intuitively reflexive about society and nature; focus [...] on common good as a core value of public life; rel[y] on inclusionary deliberation to reveal truth." (Rayner 2003, 165).

Det forventes således, at borgere med udgangspunkt i et lokalt forankret hverdagsliv og et fokus på de fælles goder er i stand til at reflektere og inddrage etiske, moralske og sociale perspektiver i dialogen om tekniske og naturvidenskabelige problemstillinger, og endvidere kan udøve et videnskabeligt medborgerskab ved at omsætte deres overvejelser til politiske anbefalinger om, hvordan disse problemer løses.

Som nævnt ovenfor er der også et demokratiske perspektiv $\mathrm{i}$ at inddrage borgere $\mathrm{i}$ diskussionen om kom- 
plekse videnskabelige og teknologiske problemstillinger - et perspektiv som udspringer af teorier om det deliberative demokrati (Habermas 1984, Dryzek 2010). Ifølge denne forståelse af demokrati skal en politisk beslutning være baseret på dialog, refleksion og afvejning af argumenter - ikke blot blandt valgte politiske repræsentanter, men også blandt de berørte borgerne. Udgangspunktet er, at borgernes holdninger til en given problemstilling ikke er givet på forhånd, men bliver formet i en dialog med andre borgere. Med andre ord forventes det, at borgerne er åbne over for argumenter - herunder argumenter baseret på videnskabelig viden - og lader sig overbevise af det, de opfatter som det bedste argument (Agger et al. 2012).

Kernen i borgerinddragelse er derfor den dialog, eller deliberation, der foregår mellem borgerne, hvor deres egne erfaringer og perspektiver bliver sat i spil og afprøvet i sammenhæng med den videnskabelige viden, der bliver lagt frem. Borgernes indbyrdes deliberation har således et formål i sig selv, idet den får de deltagende borgere til at reflektere over problemstillingen og relatere den til deres egne værdier. Deliberationen er således en del af den politiske proces i samfundet, ligegyldigt om borgernes refleksioner bliver bragt videre til de valgte politikere, som de gør i forbindelse med en struktureret borgerdialog, eller ej. De metoder til struktureret borgerinddragelse, som Teknologirådet har udviklet gennem årene, er alle baseret på principperne i deliberativt demokrati.

Den deliberative tilgang til demokrati - og dermed de metoder til borgerinddragelse, der bygger på denne tilgang - er blevet kritiseret for en række faktorer (Jæger under udgivelse). Metoderne er primært blevet kritiseret for ikke at tage højde for magtforholdene i samfundet, og at det er naivt at forstille sig, at frie individer gennem en deliberation kan finde frem til en rationel løsning på et problem (Rayner 2003, Agger et al. 2012). Derudover bliver de kritiseret for at være baseret på et udvalg af borgere, der ikke er repræsentative for hele befolkningen (Joss 1995, Jensen 2005, Reyner 2003); for ikke at have marginaliserede borgergrupper med, men derimod have en overrepræsentation af veluddannede (Felt \& Fochler 2010); for at udstikke for snævre rammer for borgernes dialog (Irwin 2001 og 2006, Jensen 2005), hvor eksperternes dagsorden sætter rammerne for borgernes dialog og dermed får lov til at dominere (Goven 2003, Blue et al. 2012), og for at de forskellige former for viden ikke bliver ligestillet (Phillips 2011). Desuden er der rejst kritik af, at borgernes holdninger ikke bliver hørt af politikerne (Joss \& Durant 1995, Einsiedel et al. 2001, Horst \& Irwin 2010), at evaluering af arrangementerne ofte er foretaget af de eksperter, der selv er involveret i gennemførelsen (Reyner 2003), og at evalueringen sjældent afdækker selve kernen i borgernes dialog (Coleman \& Moss 2012).
Kritikken viser således, at det langt fra er uproblematisk at inddrage borgere i deliberation om komplekse tekniske og videnskabelige problemer. Formålet med denne artikel er imidlertid ikke at undersøge om disse kritikpunkter slår igennem i World Wide Views eller ej. Formålet er derimod - med disse kritikpunkter i baghovedet - at sætte fokus på kernen i borgerdialogen, og undersøge hvordan borgerne forholder sig til den videnskabelige viden, der bliver lagt frem for dem, og hvordan de bruger den i deres indbyrdes dialog. Med andre ord vil jeg, gennem en empirisk analyse, undersøge, om borgerne i World Wide Views - Biodiversitet udøvede et videnskabeligt medborgerskab og dermed blev en del af processen at opbygge socialt robust viden om biodiversitet. Men først vil jeg præsentere Teknologirådet og de metoder til borgerinddragelse, det har udviklet.

\section{Teknologirådets metoder til borgerinddragelse}

Teknologirådet (TR) blev som nævnt oprettet af Folketinget i 1986 efter en række politiske kampe omkring brugen af nye teknologier i 1970'erne, som fx kampe om indførelse af atomkraft eller indførelse af informationsteknologi i typografers arbejde (Agger et al. 2012). TR blev oprettet med det dobbelte formål: 1) at servicere Folketinget med videnskabelig viden og vurderinger af ny teknologi, som kan give anledning til politiske tiltag, 2) at fremlægge samme viden for den brede befolkning for at skabe en folkelig debat om disse ofte komplekse videnskabelige og teknologiske sager (Klüver 1995).

Forbilledet ved oprettelsen af Teknologirådet var det amerikanske Congressional Office of Technology Assessment (OTA) (Klüver 1995), som blev oprettet i 1972 med det formål at informere Kongressen om mulige fordele og ulemper ved brug af ny teknologi. Hvor OTA helt undgik at komme med politiske anbefalinger og udelukkende formidlede viden om nye teknologiske og videnskabelige landvindinger (Lin 2011), var det fra start af en del af Teknologirådets formål at skabe debat både i Folketinget og blandt befolkningen. Som en del af arbejdet med at skabe debat i befolkningen - og formidle borgernes politiske anbefalinger til Folketinget - gik TR i gang med at udvikle forskellige metoder til at inddrage borgerne.

En af de første metoder til borgerinddragelse, som TR tog op var Konsensus-konferencer. TR var inspireret af nogle tidligere amerikanske teknologivurderinger indenfor medicinalindustrien, men ændrede konceptet dels ved at inddrage et panel af lægfolk i stedet for udelukkende at inddrage eksperter, og dels ved at overlade det til borgerpanelet at sætte dagsordenen for konferencen (Joss og Durant 1995, Klüver 1995). Dermed udviklede TR konsensus-konferencerne til den form, de har i dag, og TR er senere blevet internationalt kendt for at have 
udviklet konsensus-konferencer som metode til borgerinddragelse. Derudover har TR udviklet andre metoder som fx borgerhøringer og scenarie værksteder (Andersen \& Jæger 1999) - World Wide Views er blot det seneste skud på stammen.

I udviklingen af disse metoder til borgerinddragelse har TR forsøgt at tage højde for den ovenfor nævnte kritik, men har forståeligt nok ikke fundet løsninger på alle kritikpunkterne. Selvom metoderne således ikke fuldt ud lever op til idealerne for det deliberative demokrati, fortsætter TR dog med at arbejde med dem ud fra en tankegang om, at det er nødvendigt at have en pragmatisk tilgang til borgerinddragelse. Holdningen i TR er, at hvis man kun kan gennemføre arrangementer med borgerinddragelse, der kan leve op til samtlige idealer, vil det være helt umuligt at gennemføre arrangementer med borgerinddragelse i praksis. ${ }^{2}$ På denne baggrund udviklede TR World Wide Views (WWViews) som en metode til en global borgerhøring i 2009 (Bedsted et al. 2012). I WWViews er det deliberative grundlag bevaret, og dialogen mellem borgerne spiller stadig den centrale rolle, men der er ikke noget krav om konsensus, som der fx er i konsensus-konferencer.

I forbindelse med forberedelsen af WWViews - Biodiversitet indgik TR et samarbejde med Naturstyrelsen som medarrangør. Naturstyrelsen så sig selv som den part, der skulle levere det faglige indhold, mens TR leverede metoden. ${ }^{3}$ Det var således et vigtigt punkt for Naturstyrelsen at formulere både de diskussionstemaer, der dannede udgangspunkt for borgernes dialog, og de spørgsmål, som borgerne efterfølgende skulle besvare eller stemme på. Naturstyrelsen havde i forvejen et samarbejde med FN's sekretariat for biodiversitet, som forberedte FN's topmøde om biodiversitet, og Naturstyrelsen diskuterede temaer og spørgsmål med sekretariatet. På den måde blev både de overordnede temaer for dialogen og de enkelte spørgsmål tilrettelagt, så de nøje svarede til det, der skulle træffes beslutninger om på FN's topmøde.

På dagen for WWViews - Biodiversitet blev borgerne helt konkret placeret ved 16 borde med 6-8 personer og en bordformand. Ud fra fire overordnede temaer diskuterede borgerne en række spørgsmål relateret til biodiversitet samt mulige strategier til at rette op på nedgangen $i$ antallet af arter. Efter hver runde med diskussion af et tema afgav borgerne hver for sig deres stemme til nogle på forhånd formulerede spørgsmål. Som grundlag for dialogen havde borgerne dels et informationshæfte om biodiversitet (Teknologirådet 2012a), som blev sendt ud til samtlige deltagere et par uger i forvejen, dels en mundtlig præsentation til hvert tema og endelig en række film, der blev vist umiddelbart inden starten på hver af diskussionsrunderne.
Arrangementets globale karakter blev understreget af, at der løbende indløb rapporter om borgernes stemmeafgivning i de øvrige deltagende lande, som blev vist på en storskærm. På et tidspunkt blev der også etableret direkte forbindelse til WWViews i Sydafrika, så deltagerne de to steder fik mulighed for at se og høre hinanden. Resultaterne af borgernes afstemninger, både i Danmark og internationalt, er samlet i TR's afsluttende rapport (Teknologirådet 2012b), som blev præsenteret på FN's topmøde om biodiversitet i Indien i oktober 2012.

\section{Videnskabens rolle i borgernes dialog}

Det empiriske materiale, der ligger til grund for denne analyse, er indsamlet $\mathrm{i}$ forbindelse med et større forskningsprojekt, hvis resultater er under udgivelse (Philips et al. Under udgivelse). Det samlede materiale består af deltagende observationer af WWViews - Biodiversitet i København, herunder observationer af dialogen ved fem af de 16 borde. Der blev endvidere gennemført en exit survey blandt deltagerne samt et efterfølgende interview med arrangørerne fra Teknologirådet og Naturstyrelsen. Derudover består materialet af det informationshæfte, der blev udsendt til deltagerne i forvejen, de mundtlige præsentationer af de enkelte temaer på dagen, samt de indledende film til hvert tema. Endelig indgår resultaterne af borgernes afstemning i det empiriske materiale.

Det samlede empiriske materiale indgår som en baggrundsviden, hvorimod den efterfølgende analyse er baseret på udvalgte materialer. Den første del af analysen er således baseret på det udsendte informationshæfte. De mundtlige oplæg og film, der blev vist på dagen, bygger langt hen ad vejen på de samme videnskabelige kilder, og de indeholder derfor kun enkelte nye informationer. På den baggrund har jeg vurderet, at informationshæftet repræsenterer den videnskabelige viden, som borgerne blev præsenteret for, og selve analysen består af en dokumentanalyse, hvor jeg har undersøgt, hvem der optræder som eksperter, hvilken autoritet de bliver tillagt, og hvilken troværdighed den videnskabelige viden bliver tillagt.

I den anden del af analysen dykker jeg ned i dialogen ved et af bordene. Her undersøger jeg, hvordan den videnskabelige viden bliver brugt $i$ borgernes interne deliberation. Jeg kigger efter, hvem borgerne oplever som eksperter, hvilken autoritet og troværdighed de tillægger eksperterne og deres udsagn, samt hvordan borgerne selv benytter sig af den videnskabelige viden i deres argumentation med de andre borgere.

\section{Analyse af informationshæftet}

Informationshæftet er udarbejdet af Teknologirådet i samarbejde med Biofaction ${ }^{4}$ med det formål at videregive videnskabelig information om biodiversitet og potentielle 
tiltag til at modvirke nedgangen i biodiversitet til deltagerne i arrangementet. Hæftet er oversat til 20 forskellige sprog og blev brugt som udgangspunkt for samtlige WWViews arrangementer verden over. Jeg har i denne forbindelse analyseret den danske udgave af informationshæftet.

Det fremgår af forordet, at informationshæftet fokuserer på de temaer, der skal drøftes på FN's konference om biodiversitet i oktober 2012. Temaerne udgør også selve strukturen i hæftet, som efter en generel introduktion til biodiversitet indeholder et afsnit om biodiversitet på landjorden, et afsnit om biodiversitet i havet og afslutter med et afsnit om byrde- og udbyttefordelingen. Konsekvensen af dette valg er imidlertid, at det er nogle yderst komplicerede problemstillinger, borgerne bliver bedt om at forholde sig til. Samtidig bliver problemstillingerne behandlet på et overordnet og generelt niveau, som det kan være vanskeligt at forholde sig til, hvorfor man kan forvente, at borgerne kan have svært ved at bringe deres lokalt forankrede hverdagserfaringer i spil.

I forordet beskrives det, at „Informationen i dette hæfte stammer fra rapporter skrevet af videnskabsfolk fra hele verden“" (s. 3). Derudover har et videnskabeligt rådgivningspanel „dobbelttjekket oplysningerne i teksten“ (s. 3). Formålet med dette panel „... er at sikre, at det informationsmateriale, der præsenteres for borgerne, er præcist, fyldestgørende og balanceret i forhold til de spørgsmål, man beder dem drøfte." (s. 0). Dermed fremstår informationshæftet som en neutral og balanceret tekst, der videregiver den videnskabelige viden, der er konsensus omkring inden for det videnskabelige felt. Den viden, der fremlægges, er oven i købet 'dobbelttjekket', hvilket skaber stor troværdighed.

Der skelnes ikke mellem eksperter, videnskabsfolk og forskere, men når der refereres til videnskabsfolk, er det tydeligvis forskere fra naturvidenskaberne, idet de beskæftiger sig med økosystemer, klimaforandringer, opdagelse af nye arter m.m. Samfundsvidenskabelige problemstillinger som økonomiske konsekvenser, kulturelle forudsætninger og sociale forhold bliver også beskrevet i hæftet, men de optræder mest i forbindelse med overvejelser om tiltag og strategier til at mindske nedgangen i biodiversiteten og ikke som en præsentation af undersøgelser, der kortlægger sammenhængen mellem biodiversitet og de samfundsmæssige forhold.

Informationshæftet benytter sig ikke af den akademiske tradition for præcise henvisninger til navngivne publikationer i præsentationen af den videnskabelige viden. Bagerst i hæftet er der en samling referencer og yderligere læsestof, som dog ved nærmere eftersyn viser sig at være en blanding af egentlige videnskabelige publikationer og en række rapporter dels fra FN's egne organisationer ( $f x$
FAO), dels forskellige andre organisationer ( $\mathrm{fx}$ WWF, World Resources Institute og The International Centre for Integrated Mountain Development). Denne praksis betyder, at borgerne ikke kan se, hvilke publikationer der ligger til grund for de konkrete informationer, hvilket gør det vanskeligt for dem at forholde sig kritisk til den viden, der bliver inddraget i hæftet.

I hæftets første afsnit får man som læser en klar fornemmelse af, at der trækkes på videnskabelige publikationer. Det er således en (natur-)videnskabelig definition på biodiversitet, der bliver fremlagt, ligesom beskrivelsen af biodiversitetens goder, samt presset på den, også fremstår som videnskabeligt funderet. I de følgende afsnit om biodiversitet henholdsvis på landjorden og i havet bliver grænsen mellem videnskabelig viden og politiske strategier imidlertid uklar. Disse afsnit starter med en beskrivelse af problemerne, der fremstilles som videnskabeligt funderede, men glider derefter over i en diskussion af politiske strategier, hvor det ikke er muligt at se, hvem der er afsender af budskabet. Fx glider beskrivelsen af problemerne med biodiversitet på landjorden over i følgende formulering: „Problemet er derfor, hvordan man kan producere nok føde og samtidig beskytte biodiversiteten bedst muligt. Man har foreslået adskillige strategier." (s. 11 - min kursivering). Som det fremgår af citatet, er det ikke muligt at identificere, hvem 'man' er - og der er formodentlig tale om to forskellige aktørgrupper. Det er således heller ikke muligt at bestemme, hvem der har foreslået de forskellige strategier. Er det videnskabsfolk, politikere eller organisationer som fx FN - eller en blanding?

Denne uklarhed om, hvem der ligger til grund for hæftets informationer, bliver endnu mere udtalt i afsnittet om byrde- og udbyttefordeling. Her fremgår det, at der er vedtaget en fælles global strategi i 2010. Herefter følger:

„Der er generel konsensus om, at den nuværende finansiering af biodiversitet fra GEF, nationale regeringer og andre aktører langtfra er tilstrækkelig til at bremse den globale nedgang i biodiversitet.

Nogle mener, at det vil være bedre at bruge pengene på at løse mere presserende problemer end biodiversitet. Andre er af den opfattelse, at investeringen i biodiversitet vil blive en økonomisk fordel på længere sigt." (s. 17 - min kursivering).

Citatet rejser en række spørgsmål: I hvilken kreds er der generel konsensus om den utilstrækkelige finansiering? Er det blandt forskerne, der er konsensus, blandt politikerne, eller på tværs af grupperne? Og hvem mener henholdsvis, 
at der er andre presserende problemer, eller at det er en $ø$ konomisk fordel på længere sigt? Dermed bliver forskernes rolle i den politiske beslutningsproces uklar, når det ikke er til at se, om det er dem, der mener det ene eller det andet.

Alt i alt kan det konstateres, at informationshæftet fremstår som en fremlæggelse af troværdig videnskabelig viden, og de eksperter, der fremlægger den, bliver tillagt stor autoritet. Det er primært naturvidenskabelige forskere, der fremstilles som eksperter, men muligvis ligger der nogle samfundsvidenskabelige analyser bag nogle af anbefalingerne om tiltag og strategier til at mindske nedgangen i biodiversitet. Det er dog ikke til at se, da disse tiltag og strategier præsenteres i en anonymiseret form. Uklarhederne omkring, hvem der står bag den fremlagte viden og de foreslåede strategier, gør det vanskeligt for de deltagende borgere at forholde sig kritisk til oplysningerne i informationshæftet, og dermed bliver det vanskeligt at udøve et videnskabeligt medborgerskab.

\section{Analyse af dialogen mellem borgerne}

Der er ikke nogen tvivl om, at deltagerne, der sidder rundt om bordet, alle har læst det udsendte informationshæfte, og at de har stor tillid til den viden, der præsenteres i hæftet. Der er dog en af deltagerne, der mangler nogle tal om befolkningsudviklingen i informationshæftet, som kunne sættes i relation til det verdenskort over biodiversitetens størrelse, der præsenteres i hæftet (Teknologirådet 2012a, 5). Han begrunder den lille biodiversitet i Danmark med befolkningstallet og påpeger, at vi jo har fældet urskoven i Danmark for mange århundreder siden, og han opfatter det derfor som lidt umoralsk, at vi nu forlanger, at andre lande ikke må fælde deres regnskov. Det får ham til at spørge om, hvad det er for en slags biodiversitet, vi gerne vil have, og hvor vi kan have det. Han siger:

„Det er nogle ting, nogle tal, som jeg synes, der manglede rigtig meget i hele det her kompendium. Hvor jeg lige sad bagefter [og tænkte]: 'Hvad er det for en hjernevask, på nogen måder, der bliver galt i det her? Hvad er det for nogle tanker og holdninger, man vil ud med?' Jeg synes, der var nogle tal, der manglede i min verden."

Han endte med at blive sur på informationshæftet, fordi det efter hans opfattelse er præget af en holdning om, at vi skal redde biodiversiteten, og han manglede et "modfact", der viste det modsatte. Denne sidste reaktion tyder på, at han enten tænker ud fra en journalistisk form for objektivitet, hvor både fortalere og modstandere af et synspunkt skal høres, eller at han opfatter videnskaben ud fra en relativistisk synsvinkel, hvor man altid kan finde en forsker, der kommer frem til et andet resultat. Denne tilgang til videnskabelig viden bliver også fremført på et senere tidspunkt, hvilket fremgår af følgende dialog:

„Karla: Så tænker jeg bare, eksperterne, de er jo heller ikke helt enige om, hvad det er, man skal gøre, hvad det er, der er problemet. Så bliver man også selv forvirret omkring det, når eksperterne ikke engang kan blive enige om, hvad det er, der sker.

Anette: Jamen, hvad eksperterne siger. Ja, det lyder måske lidt groft. Det kommer måske også an på, hvad de er betalt for at sige. Hvis en ekspert bliver hyret til at sige, at det er ok at anlægge et nyt fabriksanlæg her. Så finder han beviser for det. Hvis han bliver hyret til at sige, at det er farligt, at polerne smelter, så finder han ud af det. Så... man skal sådan lytte lidt ind på det, for eksperterne de siger det, de er blevet betalt for at sige - i hvert fald meget af tiden.

Henrik: Vil du så helt generelt sige, at vi skal lade være med at lytte til, hvad eksperterne siger?

Anette: Nej, jeg siger, at vi skal lytte til alle eksperterne og så drage vores konklusioner ud fra det.

Henrik: Jeg tror da stadigvæk på, at når forskere forsker i et eller andet område, så er det sandheden, man prøver at finde frem til. Hvis man derimod har en ekspert fra en virksomhed, så ved man jo godt, at han eller hun taler virksomheden sag."

Dette udpluk af dialogen blandt deltagerne viser, at de mener, at der er forskel på eksperter, og ved at forholde sig kritisk til dem, udøver deltagerne et videnskabeligt medborgerskab. Flere af deltagerne giver udtryk for, at de har registreret, at nogle forskere søger efter sandheden, mens andre er betalt til at finde et bestemt svar. Det fremgår ikke direkte af dialogen, men den kan tolkes som, at deltagerne mener, at de forskere, der søger efter sandheden, er økonomisk uafhængige (dvs. offentligt ansatte), mens dem, der er betalt for at finde bestemte svar, er ansatte i virksomheder eller interesseorganisationer. Senere i dialogen bliver det fremført af en af deltagerne, at det også er legitimt, at $\mathrm{fx}$ en virksomhed ansætter eksperter til at 
varetage deres interesser, da virksomheder også er en del af den samlede politiske debat. Disse eksperter bliver således ikke lagt for had, men som det også fremgår af citatet, mener deltagerne, at man som borger skal forholde sig kritisk til deres udsagn. Med andre ord, deres udsagn har ikke den samme troværdighed, som de uafhængige forskeres har. Deltagerne tilkendegiver hermed, at det er vigtigt at kunne skelne mellem, hvilken slags ekspert der fremkommer med et givet udsagn, idet de tillægges forskellig autoritet.

I resten af dialogen rundt om bordet bliver den videnskabelige viden, der er lagt frem gennem informationshæftet, tillagt stor troværdighed. Både i dialogen om biodiversitet på landjorden og i dialogen om biodiversitet i havet bliver den videnskabelige viden tillagt større troværdighed end landmændenes og fiskernes udsagn. Det fremgår af følgende udpluk af dialogen:

„Theis: ... Jeg synes, der skal komme nogle undersøgelser om, hvor meget kan man egentlig tillade sig at fiske, for at det stadig kan rende rundt.

Anette: Ja, jeg tror, vi skal have videnskabsmændene til at sige mere om det end fiskerne, fordi fiskerne vil selvfølgelig sige, at de skal fange mere, for at tjene penge. Og jeg ved godt, det er rimelig kynisk at sige om fiskerne, for selvfølgelig er der sikkert mange fiskere, der gerne vil bevare biodiversiteten (...), men jeg tror, det er videnskabsmændene, der skal sige mest om det.

Henrik: Den diskussion, som fiskerne og videnskabsmændene har, den synes jeg er falsk, fordi videnskabsmændene vil altid have en større baggrund for at fortælle, hvad det er, der er galt. Fiskerne kan sige: 'Det område, hvor jeg plejer at fiske, der er stadigvæk mange fisk', men det siger jo ikke noget som helst om overfiskeri... Jeg mener, man bør stole på de videnskabsmænd, der kommer med kvoterne.

Anette: Også fordi... så kan en videnskabsmand bedre være objektiv."

Derudover viser udplukket, hvordan deltagerne bruger informationshæftet, hvor diskussionen om fiskernes og videnskabsfolkenes forskellige syn på kvoter også er repræsenteret (Teknologirådet 2012a, 13). Udplukket viser dermed, at dialogen langt hen ad vejen er bundet op på den struktur, der både er givet $\mathrm{i}$ informationshæftet og i de afstemningstemaer, som afslutter de enkelte runder af dialog. På den måde kan det være vanskeligt at bringe andre emner på banen, end de på forhånd beskrevne temaer.

Som beskrevet ovenfor er diskussionstemaerne holdt på et generelt niveau (for at matche diskussionen på FN's topmøde), hvilket kan gøre det vanskeligt for borgerne at bringe deres egne erfaringer i spil. Ved det bord, som denne analyse tager udgangspunkt $i$, udspillede der sig en proces, hvor de generelle perspektiver og borgernes egne perspektiver konkurrerede om at dominere dialogen (Phillips m.fl. under udgivelse). I mange tilfælde blev det generelle perspektiv på biodiversitet det dominerende, men det lykkedes dog deltagerne under flere af temaerne at relatere den generelle diskussion til et spørgsmål om deres egne holdninger og handlinger som borgere. Flere af dem gav udtryk for, at vi alle har et ansvar, hvilket bliver formuleret på følgende måde af en af deltagerne:

„... Så det siger noget om, hvor vigtigt det er, at der også bliver taget hånd om de små ting, ikke? Og det er også derfor, at det er så spændende at være med, fordi jeg tror jo meget på, øh... ansvar. Ansvar for sig selv først og fremmest og dernæst for dem, som vi omgiver os med."

Denne holdning gik igen i flere af dialogerne og gjorde det lettere for deltagerne at forholde de generelle diskussioner om biodiversitet til deres egne erfaringer. Et eksempel på dette er dialogen om biodiversitet på landjorden. En af de problemstillinger, som informationshæftet rejser indenfor dette tema, drejer sig om det stigende kødforbrug, der fører til et øget behov for at opdyrke jorden for at skaffe planter til dyrefoder. Informationshæftet skitserer flere forskellige strategier til løsning af problemet: mindre intensivt landbrug, brug af ny teknologi, brug af konventionelle praksisser eller at sænke efterspørgslen på fødevarer ved at spise mindre kød og lade mindre mad gå til spilde (Teknologirådet 2012a, 11). En del af den dialog, der udspillede sig rundt om bordet, handlede om, hvorvidt man som borger har et ansvar for at mindske nedgangen i biodiversitet ved at mindske sit kødforbrug eller helt at holde op med at spise kød. Ved således at tage udgangspunkt i den enkeltes ansvar formår deltagerne rundt om bordet at koble den generelle diskussion til deres egen erfaringer og holdninger. På den måde skaber de en socialt robust viden om, hvordan borgere forholder sig til deres egen indsats for at bevare biodiversiteten.

Deltagernes dialog drejede herefter over i en debat om, hvorvidt samfundet skal regulere befolkningens kødforbrug, og om sådan en regulering skal ske gennem kvo- 
ter eller afgifter, hvilket kan ses som et konkret eksempel på, at borgerne udøver et videnskabeligt medborgerskab, i kraft af at de diskuterer hvilke politiske løsninger, der kan være. Som konsekvens af holdningen om at den enkelte borger har et ansvar, var gruppen rundt om bordet enig om, at det er nødvendigt at have befolkningens opbakning til sådanne politikker - ellers vil det være umuligt at skabe forandring. Her mener deltagerne, at oplysning og formidling af videnskabelig viden kommer ind som vigtige styringsredskaber, idet folk skal være klar over, hvorfor reglerne er lavet, ellers kan de modsætte sig at overholde dem. Som illustration af denne pointe nævner en af deltagerne et eksempel med landmænd, der nægter at overholde en ny randzone lov, fordi de ikke kan se nødvendigheden af den. Omvendt mener gruppen, at hvis befolkningen er med på at overholde nye regler, kan man nå langt i målet om at mindske nedgangen i biodiversitet. Det udtrykte en af deltagerne på følgende måde:

„Jeg synes, man i pressen hører om så mange ting. For eksempelvis i Stillehavet, at der er kæmpe områder, hvor det flyder med plastic og sådan noget, og det er så voldsomt, så man ind imellem har lyst til at sige: 'Jamen det her, det magter vi ikke. Vi har ødelagt jorden, og det må gå sin skæve gang'. Når man så er i København og kan se, at man kan bade i havneanlægget - man har formået i Danmark at rense så meget, at det kan bruges igen - så er der jo et håb, en vej ud af det her, måske. Men om det er sidste øjeblik, det ved jeg ikke noget om. Men der er et håb, og det synes jeg, vi skal udnytte, det håb."

Opsummerende kan det konstateres, at den videnskabelige viden, der bliver præsenteret gennem informationshæftet, bliver tillagt stor troværdighed og spiller en meget stor rolle i borgernes dialog om biodiversitet. Sammen med valget af diskussionstemaer sætter den videnskabelige viden en strukturerende ramme for borgernes dialog både med hensyn til, hvad det overhovedet er muligt at diskutere, og med hensyn til, hvilke perspektiver der er legitime at tage op. Videnskabelige eksperter bliver generelt tillagt stor autoritet, men samtidig mener borgerne også, at der er forskel på eksperter, og nogle eksperter har større autoritet end andre. De eksperter, der er ansat til at varetage bestemte virksomheders eller organisationers interesser, skal man som borger forholde sig kritisk til.

\section{Konklusion}

I indledningen til denne artikel stillede jeg spørgsmål om, hvordan videnskabelig viden bliver præsenteret for borgere i strukturerede gruppeprocesser, og hvordan borgerne forholder sig til denne viden i deres indbyrdes deliberation, når de skal finde frem til de råd, som de vil sende videre til politikerne. Ved at trække på teoretiske diskussioner inden for STS samt en tilgang til deliberativt demokrati udstak jeg en teoretisk ramme for den empiriske analyse. Ifølge denne teoretiske ramme kan inddragelse af lægfolk i diskussionen om videnskabelige og teknologiske problemer forstås som en proces, der skaber socialt robust viden. Gennem denne proces forventes det, at borgere udøver et videnskabeligt medborgerskab ved at forholde sig kritisk til den fremlagte videnskabelige viden og føje deres egne perspektiver til denne viden.

Samlet kan det konkluderes, at videnskabelig viden spiller en afgørende rolle i borgernes indbyrdes deliberation, og når de formulerer anbefalinger til politikerne. Den empiriske analyse af, hvordan videnskabelig viden indgår i borgernes dialog på WWViews - Biodiversitet viser, at denne viden skaber en strukturerende ramme for borgernes dialog, i og med at borgerne tager udgangspunkt i den i deres indbyrdes deliberation. Analysen viser endvidere, at borgerne generelt tillægger videnskabelig viden stor troværdighed. Dog mener de også, at ikke alle eksperter har lige stor autoritet. De uafhængige eksperter, der alene udtaler sig som repræsentanter for deres faglige felt, bliver således tillagt en væsentlig større autoritet end de eksperter, der er ansat til også at repræsentere en virksomheds eller organisations interesser.

Hvis borgerne skal udøve videnskabeligt medborgerskab og forholde sig kritisk til den fremlagte videnskabelige viden, bliver det således vigtigt, at de har kendskab til, hvilken slags ekspert der fremlægger den pågældende viden. Analysen af informationshæftet viser imidlertid, at der er en del uklarhed omkring kilderne til de enkelte oplysninger og forslag til løsningsstrategier. Uklarheden er muligvis fremkommet på baggrund af et ønske om at fremstille den komplicerede problemstilling på en forståelig og populær måde, men konsekvensen er, at borgerne ikke kan kigge eksperterne over skulderen, og dermed får de ikke mulighed for i fuldt omfang at udøve deres videnskabelige medborgerskab, som det ellers forventes ved institutionaliserede metoder til borgerinddragelse som WWViews.

Ud over den fremlagte videnskabelige viden er valget af diskussionstemaer også med til at strukturere borgernes deliberation. Diskussionstemaerne var, som beskrevet, udvalgt med det formål, at resultaterne af deliberationen skulle føde direkte ind i beslutningsprocessen på FN's topmøde om biodiversitet. Konsekvensen af dette 
valg er imidlertid, at problemstillingen omkring biodiversitet bliver præsentret på et ret generelt niveau, der gør det vanskeligt for borgerne, at relatere den fremlagte videnskabelige viden til deres egne erfaringer. Valget af diskussionstemaer gør det endvidere vanskeligt for borgerne at bringe andre temaer og perspektiver på biodiversitet op til debat, hvormed udøvelsen af et videnskabeligt medborgerskab besværliggøres.

Ved det analyserede bord lykkedes det i en vis udstrækning borgerne at inddrage deres personlige perspektiver på problemstillingen i kraft af, at de var enige om, at man som borger har et ansvar for, hvordan biodiversiteten udvikler sig, og at man i kraft af sine handlinger kan påvirke denne udvikling. Dermed formår de at tilføje en viden om, hvor langt de selv vil gå for at bevare biodiversiteten, og bliver dermed en del af processen at skabe socialt robust viden omkring biodiversitet. Ved at flytte fokus fra, at resultaterne af borgerinddragelsen skal bruges direkte i den formelle politiske beslutningsproces, til et fokus på processen at skabe socialt robust viden, vil det formodentlig være muligt i kommende borgerinddragelses processer at vælge diskussionstemaer, der gør det lettere for borgerne mere direkte at bidrage til processen at skabe socialt robust viden med perspektiver baseret på deres egne erfaringer og værdier.

Endelig er det vigtigt at huske, at denne konklusion er baseret på en analyse af en struktureret gruppeproces med det formål at inddrage borgere i den politiske løsning af videnskabelige og teknologiske komplekse problemstillinger. Analysen siger dermed ikke noget om, hvordan videnskabelig viden indgår $\mathrm{i}$ andre sammenhænge, hvor borgere forholder sig til disse problemstillinger, ligesom den heller ikke siger noget om, hvorvidt andre forslag til løsninger er baseret på en socialt robust viden.

\section{Referencer}

Agger, A, Jelsøe, E, Jæger, B \& Phillips, L 2012, 'The Creation of a Global Voice for Citizens: The Case of Denmark', in M Rask, R Worthington \& M Lammi (red.), Citizen Participation in Global Environmental Governance, Earthscan, London.

Andersen, I-E \& Jæger, B 1999, 'Scenario workshops and consensus conferences: towards more democratic decision-making', Science and Public Policy, vol. 26, no. 5, pp. 331-340.

Bedsted, B, Gram, S \& Klüver, L 2012, 'The Story of World Wide Views', in M Rask, R Worthington \& M Lammi (red.), Citizen Participation in Global Environmental Governance, Earthscan, London.

Blue, G, Medlock, J \& Einsiedel, E 2012, 'Representativeness and the Politics of Inclusion: Insights from World Wide Views Canada', in M Rask, R Worthington \& M Lammi (red.), Citizen Participation in Global Environmental Governance, Earthscan, London.

Coleman, S \& Moss, G 2012, 'Under Construction: The Field of Online Deliberation Research', Journal of Information Technology and Politics, vol. 9, pp. 1-5.
Collins, HM \& Evans, R 2002, 'The Third Wave of Science Studies: Studies of Expertise and Experience', Social Studies of Science, Vol. 32, no. 2, pp. 235-296.

Dryzek, JS 2010, Foundations and Frontiers of Deliberative Governance, Oxford University Press, Oxford.

Einsiedel, F, Jelsøe, E \& Breck, T. 2001, 'Publics at the technology table: the consensus conference in Denmark, Cananda, and Australia', Public Understanding of Science, vol. 10, pp. 83-98.

Felt, U \& Fochler, M 2010, 'Machineries for Making Publics: Inscribing and De-scribing Publics in Public Engagement' Minerva, vol. 48, no. 3, pp. 219-238.

Goven, J 2003, 'Deploying the consensus conference in New Zealand: democracy and de-problematization', Public Understanding of Science, vol. 12, pp. 423-440.

Habermas, J 1984, The Theory of Communicative Action Vol. 1: reason and the rationalization of society, Beacon Press, Boston MA.

Horst, M \& Irwin, A 2010, 'Nations at Ease with Radical Knowledge. On Consensus, Consensusing and False Consensusness', Social Studies of Science, vol. 40, no. 1, pp. 1-22.

Irwin, A 2001, 'Constructing the scientific citizen: Science and democracy in the biosciences', Public Understanding of Science, vol. 10, pp. 1-18.

Irwin, A 2006, 'The Politics of Talk: Coming to Terms with the 'New' Scientific Governance', Social Studies of Science, vol. 36, pp. 299 320.

Jasanoff, S 2003, '(No?) Accounting for expertise', Science and Public Policy, vol. 30, no. 3, pp. 157-162.

Jensen, CB 2005, 'Citizen Projects and Consensus-Building at the Danish Board of Technology: On Experiments in Democracy', Acta Sociologica, vol. 48, no 3, pp. 221-235.

Joss, S 1995, 'Evaluating consensus conferences', in Joss, S \& Durant, $\mathrm{J}(\mathrm{red})$, Public participation in science: the role of consensus conferences in Europe, Science Museum with the support of the European Commission Directorate General XII, London.

Joss, S \& Durant, J (red.) 1995, Public participation in science: the role of consensus conferences in Europe. Science Museum with the support of the European Commission Directorate General XII, London.

Jæger, B Under udgivelse, 'Multiple Voices in Deliberative Global Governance', in Coleman, S, Sintomer, Y \& Przybylska, A (red.), Deliberations: values, processes, institutions.

Klüver, L 1995, 'Consensus conferences at the Danish Board of Technology', in Joss, S \& Durant, J(red.), Public participation in science: the role of consensus conferences in Europe, Science Museum with the support of the European Commission Directorate General XII, London.

Lin, AC 2011, 'Technology Assessment 2.0: Revamping Our Approach to Emerging Technologies', Brooklyn Law Review, vol. 76, no. 4, pp. 1309-1370.

Nowotny, H, Scott, P \& Gibbon, M 2001, Re-Thinking Science. Knowledge and the public in an Age of Uncertainty, Polity Press, Cambridge.

Nowotny, H 2003, 'Democratising expertise and socially robust knowledge', Science and Public Policy, vol. 30, no. 3, pp. 151-156.

Phillips, L 2011, The Promise of Dialog. The dialogic turn in the production and communication of knowledge, John Benjamins Publishing Company, Amsterdam.

Phillips, L, Jæger, B, Jelsøe, E \& Agger, A Under udgivelse, 'Construction the 'Citizen' in Global Deliberations', in Rask, M \& Worthington, R Governing biodiversity through democratic deliberation, Earthscan, London. 
Rayner, S 2003, 'Democracy in the age of assessment: reflections on the roles of expertise and democracy in public-sector decision making', Science and Public Policy, vol. 30, no. 3, pp. 163-170.

Teknologirådet 2012a. World Wide Views - Biodiversitet. Informationshafte, (http://biodiversity.wwviews.org/).

Teknologirådet 2012b. World Wide Views on Biodiversity. From the WorId's Citizens to the Biodiversity Policymakers. Results Report, (http:// biodiversity.wwviews.org/).

Wynne, B 1989, 'Sheep Farming after Chernobyl: A Case Study in Communicating Scientific Information', Environment: Science and Policy for Sustainable Development, vol. 31, no. 2, pp. 10-39.

\section{Noter}

1. Det er således udelukkende den danske del af WWViews - Biodiversitet, der bliver analyseret i denne artikel. De globale aspekter af borgerhøringen bliver behandlet i Phillips et al. (under udgivelse).

2. Interview med arrangørerne af WWViews on Global Warming fra Teknologirådet d. 24. november 2009.

3. Interview med den medarbejder fra Naturstyrelsen, der koordinerede arbejde med Teknologirådet, d. 13. marts 2013.

4. Biofaction er en østrigsk virksomhed med speciale i kommunikation af forskning og videnskab - se www.biofaction.com. 